\title{
PERBEDAAN PENGETAHUAN MAHASISWA DIPLOMA III KEBIDANAN SEBELUM DAN SESUDAH PELATIHAN KEGAWATDARURATAN MATERNAL NEONATAL
}

\author{
DIFFERENCES IN KNOWLEDGE OF MIDWIFERY DIPLOMA III STUDENTS \\ BEFORE AND AFTER MATERNAL NEONATAL EMERGENCY TRAINING
}

\author{
Fitriani Nur Damayanti ${ }^{1)}$, Lia Mulyanti ${ }^{2)}$, Dian Nintyasari Mustika ${ }^{3)}$ \\ ${ }^{1) 23)}$ Program Studi DIII Kebidanan Fakultas Ilmu Keperawatan dan Kesehatan \\ Universitas Muhammadiyah Semarang \\ Email : fitriani@unimus.ac.id
}

\begin{abstract}
ABSTRAK
Indonesia merupakan salah satu negara yang rawan terhadap semua jenis bencana yang tidak semuanya dapat diperkirakan datangnya dan tidak semuanya dapat dicegah. Bencana tersebut dapat berupa bencana alam maupun bencana akibat perbuatan manusia. Diantara semua jenis bencana, bencana alam merupakan bencana yang paling sering terjadi dan kerap menyebabkan korban jiwa dan dampak kerusakan yang hebat. Diantara semua jenis bencana, bencana alam merupakan bencana yang paling sering terjadi dan kerap menyebabkan korban jiwa dan dampak kerusakan yang hebat. Kegiatan pelatihan kegawatdaruratan ini juga menunjang visi dan misi Progam Studi D III Kebidanan FIKKES UNIMUS dalam hal mahasiswa mampu melakukan manajemen kegawatdaruratan pada maternal dan neonatal. Dan menambah pengetahuan dan pengalaman baru dalam penanganan kegawatdaruratan pada maternal dan neonatal bagi mahasiswa kebidanan. Jenis penelitian ini adalah Pre-eksperiment. Penelitian ini dilakukan dengan menggunakan kuesioner. Rancangan penelitian ini menggunakan rancangan penelitian One Group Design Pretest-Postest, yaitu suatu penelitian untuk melihat perbedaan sebelum dan sesudah diberikan treatment. Berdasarkan hasil penelitian diatas bahwa tidak ada perbedaan antara sebelum pelatihan kegawatdaruratan dan setelah pelatihan. Mahasiswa yang mengikuti pelatihan merupakan mahasiswa semester V. Mahasiswa sudah memiliki skill dasar dalam praktek di kampus dan dilahan. Sehingga sudah terbiasa dalam menangani kasus kegawatdaruratan. Ketika pelatihan kegawatdaruratan peserta bisa menyelesaikan kasus yang telah diujikan. Maka memiliki hasil maksimal dalam pelatihan. Tidak ada perbedaan pengetahuan mahasiswa DIII Kebidanan Universitas Muhammadiyah Semarang sebelum dan sesudah pelatihan kegawatdaruratan maternal dan neonatal.
\end{abstract}

Kata Kunci : Pengetahuan, Mahasiswa DIII Kebidanan, Kegawatdaruratan Maternal Neonatal

\section{ABSTRACT}

Indonesia is one country prone to all types of disasters that are not all predictable and not all can be prevented. The disaster can be a natural disaster or a disaster caused by human actions. Among all types of disasters, natural disasters are the most frequent and often deadly disaster and devastating impacts. Among all types of disasters, natural disasters are the most frequent and often deadly disaster and devastating impacts. This emergency training program also supports the vision and mission of D III Program of Midwifery FIKKES UNIMUS in terms of the students are able to perform emergency management on maternal and neonatal. And add new knowledge and experience in the management of maternal and neonatal emergency for obstetric students. This type of research is Pre-experiment. This research was conducted by using questionnaire. The design of this study using the design of One Group Design Pretest-Postest research, which is a study to see the difference before and after treatment. Based on the results of the above research that there is no difference between before emergency training and after training. Students who 
attend the training are students of semester $V$. Students already have basic skills in practice on campus and dilahan. So it is used in handling emergency cases. When the emergency training participants can solve the cases that have been tested. Then have maximum results in training. There is no difference of knowledge of DIII students of Midwifery of Muhammadiyah University of Semarang before and after training of maternal and neonatal emergency.

Keywords: Knowledge, DIII Midwifery Student, Maternal Neonatal Emergency

\section{PENDAHULUAN}

Indonesia merupakan salah satu negara yang rawan terhadap semua jenis bencana yang tidak semuanya dapat diperkirakan datangnya dan tidak semuanya dapat dicegah. Bencana tersebut dapat berupa bencana alam maupun bencana akibat perbuatan manusia. Diantara semua jenis bencana, bencana alam merupakan bencana yang paling sering terjadi dan kerap menyebabkan korban jiwa dan dampak kerusakan yang hebat.

Banyak pihak telah berupaya memberikan pelayanan kesehatan pada kondisi krisis akibat bencana, namun masih terbatas pada penanganan masalah kesehatan secara umum, sedang kondisi darurat pada ibu hamil dan anak masih belum diprioritaskan dan sering kali tidak tersedia. Padahal kondisi darurat tetap saja ada ibu-ibu hamil yang membutuhkan pertolongan, tetap ada proses kelahiran yang tidak bisa ditunda ataupun adanya kebutuhan akan layanan keluarga berencana termasuk kebutuhan khusus perempuan. Dalam kondisi darurat resiko terjadinya kekerasan berbasis gender cenderung meningkat sehingga perlu adanya upaya pencegahan maupun penanganannya.

Guna mewujudkan tersedianya pelayanan kesehatan reproduksi yang berkualitas pada situasi apapun diperlukan kesiapsiagaan semua pihak lintas sektoral dan lintas program, baik dari pemerintah maupun non pemerintah. Penanggulangan bencana adalah seluruh kegiatan yang meliputi aspek perencanaan penanggulangan bencana pada sebelum, saat dan sesudah terjadi bencana mencakup tanggap darurat, pemulihan, pencegahan, mitigasi dan kesiapsiagaan.

Diantara semua jenis bencana, bencana alam merupakan bencana yang paling sering terjadi dan kerap menyebabkan korban jiwa dan dampak kerusakan yang hebat. Tsunami yang melanda provinsi Nangroe Aceh Darusalam (NAD) dan Sumatera Utara pada akhir tahun 2004 menyebabkan kematian lebih dari 160,000 orang, 37,000 orang hilang dan 500.000 penduduk kehilangan rumah. Menyusul Tsunami, Gempa besar melanda Propinsi Daerah Istimewa Yogyakarta (DIY) dan Jawa Tengah (Jateng) pada akhir bulan Mei 2006 dan merusak lebih dari 550.000 rumah penduduk, 5.760 korban jiwa dan 37,000 korban luka. Setelah kejadian dua bencana besar tersebut, bencana lain datang silih berganti seperti tsunami di pantai selatan Pangandaran, Cilacap sampai Yogyakarta, dan tanah longsor di Sumatera Barat dan beberapa bencana di daerah lainnya.

Kegiatan pelatihan kegawatdaruratan ini juga menunjang visi dan misi Progam Studi D III 
Kebidanan FIKKES UNIMUS dalam hal mahasiswa mampu melakukan manajemen kegawatdaruratan pada maternal dan neonatal. Dan menambah pengetahuan dan pengalaman baru dalam penanganan kegawatdaruratan pada maternal dan neonatal bagi mahasiswa kebidanan.

Pelatihan kegawatdaruratan bertujuan untuk mengenalkan peserta didik kasus-kasus manajerial dalam setting situasi bencana mulai dari Pra bencana, bencana dan pasca bencana pada kesehatan maternal dan neonatal, melakukan tindakan penyelamatan di berbagai medan bencana dalam kesehatan maternal dan neonatal, merancang Explorer Search And Rescue Operation (E-SAR), mendesain rumah sakit darurat bencana, melakukan tindakan penyelamatan di rumah sakit darurat.

Hal ini sangat diperlukan karena mahasiswa Program Studi DIII Kebidanan Universitas Muhammadiyah Semarang tersebar di seluruh wilayah Indonesia. Sehingga dengan mengikuti kegiatan ini setelah lulus dapat menjadi bidan yang siap siaga terhadap bencana.

Tujuan penelitian ini adalah untuk mendeskripsikan efektivitas pelatihan kegawatdaruratan maternal neonatal pada mahasiswa Diploma III Kebidanan Universitas Muhammadiyah Semarang.

\section{METODE PENELITIAN}

Jenis penelitian ini adalah Preeksperiment. Penelitian ini dilakukan dengan menggunakan kuesioner. Rancangan penelitian ini menggunakan rancangan penelitian One Group Design Pretest-Postest, yaitu suatu penelitian untuk melihat perbedaan sebelum dan sesudah diberikan treatment (Arikunto, 2006).

Populasi dalam penelitian ini adalah mahasiswa Program Studi DIII Kebidanan Universitas Muhammadiyah Semarang yaitu 24 orang. Sampel ini adalah sampel jenuh yaitu sejumlah 24 orang. Variabel dalam penelitian ini adalah pelatihan kegawatdaruratan pada mahasiswa Diploma III Kebidanan Universitas Muhammadiyah Semarang. Analisis yang digunakan dalam penelitian ini adalah $\mathrm{Uji} T$ Berpasangan (Paired Samples Test).

\section{HASIL DAN PEMBAHASAN}

Tabel 1. One-Sample KolmogorovSmirnov Test

\begin{tabular}{|ll|r|}
\hline & & $\begin{array}{c}\text { Unstanda } \\
\text { rdized } \\
\text { Predicted } \\
\text { Value }\end{array}$ \\
\hline $\mathrm{N}$ & Mean & 24 \\
Normal & Std. & 36.89583 \\
Parameters ${ }^{\mathrm{a}, \mathrm{b}}$ & Deviatio & 33 \\
& $\mathrm{n}$ & 53 \\
Most Extreme & Absolute & .220 \\
Differences & Positive & .220 \\
Kolmogorov-Smirnov Z & -.151 \\
Asymp. Sig. (2-tailed) & 1.080 \\
\multicolumn{2}{l|}{ Negative } & .194 \\
\hline
\end{tabular}

a. Test distribution is Normal.

b. Calculated from data.

Tabel 1 merupakan tabel output hasil uji normalitas menggunakan uji Kolmogorov-Smirnov Test. Pada hasil tersebut dapat dilihat bahwa nilai Asymp. Sig. (2-tailed) menunjukkan nilai 0.194 yang artinya lebih dari alfa (a) $5 \%(0.194<0.05)$ sehingga hipotesis H0 diterima. Karena H0 diterima maka data nilai merupakan 
data yang berdistribusi normal. Karena data sudah memenuhi asumsi normalitas. Maka selanjutnya bisa dilakukan uji beda untuk data tersebut.

Tabel 2. Paired Samples Statistics

\begin{tabular}{|rl|r|r|r|r|}
\hline & & Mean & \multicolumn{1}{|c|}{ N } & Std. Deviation & Std. Error Mean \\
\hline \multirow{2}{*}{ Pair 1 } & PRE & 38.7500 & 24 & 3.53553 & .72169 \\
& POST & 38.9583 & 24 & 8.90520 & 1.81777 \\
\hline
\end{tabular}

Tabel 2. menunjukkan statistic deskriptif dari data nilai siswa. Dapat dilihat bahwa untuk data sebelum maupun sesudah diberi perlakuan terdapat 24 responden dengan rata-rata masing-masing adalah sebesar 38.7500 dan 38.9583. Sedangkan standar deviasi untuk data sebelum diberi perlakuan adalah sebesar 3.53553 dan standar deviasi untuk data setelah diberi perlakuan adalah sebesar 8.90520 .

Tabel 3. Paired Samples Correlations

\begin{tabular}{|ll|r|r|r|}
\hline & \multicolumn{1}{|c|}{$\mathrm{N}$} & Correlation & \multicolumn{1}{c|}{ Sig. } \\
\hline Pair 1 & PRE \& POST & 24 & -.009 & .968 \\
\hline
\end{tabular}

perlakuan. Adapun besarnya korelasi

Pada Tabel 3. menjelaskan tentang adanya korelasi antara kedua data yaitu data sebelum dan data sesudah diberi atau hubungan antara kedua data tersebut adalah sebesar 0.968 atau sebesar $96.8 \%$.

Tabel 4. Paired Samples Test

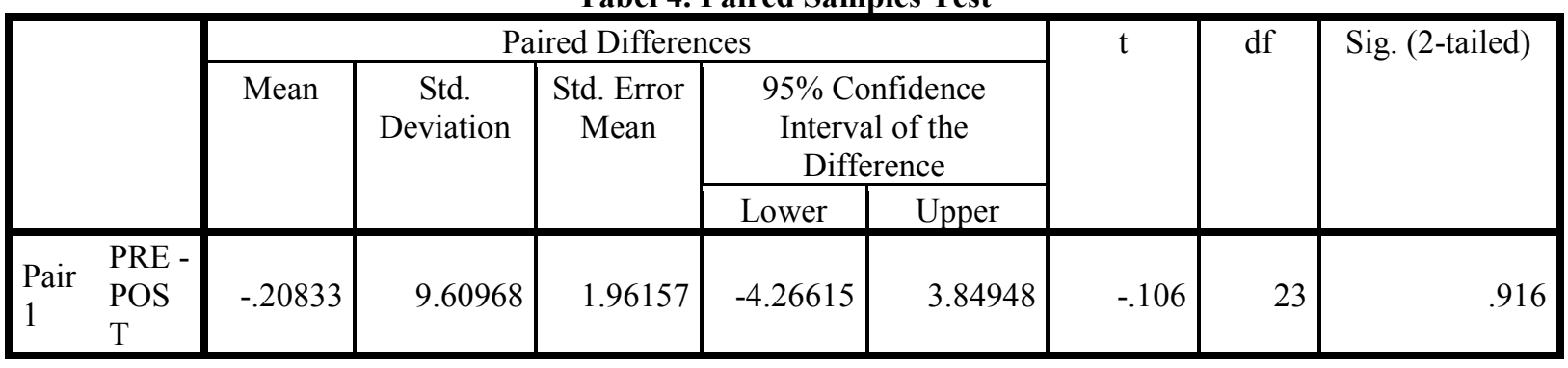

Sedangkan Tabel 4 adalah hasil tabel untuk hasil uji perbedaan nilai sebelum dan sesudah diberi perlakuan. Dapat dilihat bahwa pada hasil tersebut terdapat nilai sig.(2-tailed) sebesar 0.916 yang artinya lebih dari alfa $(\alpha)$ $5 \%(0.916<0.05)$ sehingga hipotesis beberapa data memiliki data yang lebih baik sebelum diberi perlakuan daripada sesudah diberi perlakuan.
H0 diterima. Karena H0 diterima maka dapat disimpulkan bahwa tidak terdapat perbedaan yang signifikan antara nilai sebelum dan sesudah diberi perlakuan. Hal ini dapat terjadi karena data nilai sebelum dan sesudah cenderung sama bahkan 
Berdasarkan hasil penelitian diatas bahwa tidak ada perbedaan antara sebelum pelatihan kegawatdaruratan dan setelah pelatihan. Mahasiswa yang mengikuti pelatihan merupakan mahasiswa semester V. Mahasiswa sudah memiliki skill dasar dalam praktek di kampus dan dilahan. Sehingga sudah terbiasa dalam menangani kasus kegawatdaruratan. Ketika pelatihan kegawatdaruratan peserta bisa menyelesaikan kasus yang telah diujikan. Maka memiliki hasil maksimal dalam pelatihan.

\section{SIMPULAN}

Tidak ada perbedaan pengetahuan mahasiswa DI II Kebidanan Universitas Muhammadiyah Semarang sebelum dan sesudah pelatihan kegawatdaruratan maternal dan neonatal.

\section{DAFTAR PUSTAKA}

Arikunto, S. 2006. Prosedur Penelitian Suatu Pendekatan Praktek. Jakarta: Rineka Cipta.

Boswick, John. A. 2007. Perawatan Gawat darurat. Jakarta : EGC.
European Resuscitation Council. 2005. Guidelines for Resuscitation. http://www.ukaachen.de/go/show?ID $=$ 274013\&DV $=0 \& C O M P=$ download $\& N$ $\mathrm{AVID}=1243274 \& \mathrm{NAVDV}=0 . \quad$ diakses tanggal 20 Desember 2010.

Gunadin, U. 2010. PPGD (Penanggula ngan Penderita GawatDarurat). https://profiles.google.com/1114791602 09022061653/posts/VvpoBSXtcwe/PP GDPertolonganPertama-GawatDarurat\#111479160209022061653/poss /VvpoBSXt-cwediakses tanggal 20 Desember 2010.

Hermawan, H. 2011. Hubungan pengetahuan Perawat tentang Kegawatan Napas dengan Sikap Penanganan Gawat Nafas pada Neonatus di Ruang Perawatan Intensif PKU Muhammadiyah Delanggu Klaten. Skripsi. tidak dipublikasikan STIKES Surya Global Yogyakarta. 